\title{
"Witnessing" Lynching in Scholarship and in the Classroom
}

\author{
Jenny Woodley* \\ Nottingham Trent University \\ *Corresponding author. E-mail: Jenny.woodley@ntu.ac.uk
}

Keywords: lynching; pedagogy; spectacle; memory

Amy Louise Wood's Lynching and Spectacle: Witnessing Racial Violence in America, 1890-1940 was published in 2009, just as I finished my $\mathrm{PhD}$ on the cultural campaigns of the NAACP. My project included chapters on the Birth of a Nation and images of lynching, topics also covered by Wood. I didn't have chance to read it before I submitted (by that stage I deliberately avoided reading anything that might have made me question my arguments). But as I turned my thesis into a book manuscript, Wood's analysis of lynching as spectacle helped me to refine and develop my own thinking. Just as importantly, it has influenced how I have taught the topic of lynching to undergraduate and postgraduate students. ${ }^{1}$

Lynching and Spectacle builds on the scholarship of historians such as Fitzhugh Brundage and focuses on lynching as a form of specifically white supremacist mob violence rather than considering the broader history of lynching. ${ }^{2}$ Brundage's landmark study identifies and differentiates between different types of lynching. It explains why lynchings occurred (and why there were fewer lynchings in some areas) and documents opposition to mob violence. ${ }^{3}$ Wood is less concerned with differences between types of lynching (though she recognizes such differences exist); instead, she argues that all lynchings were "sensational." Her work, rather than explaining the causes of lynching, puts it in its wider cultural context. The focus of Lynching and Spectacle isn't the act of lynching itself but its representation, particularly in images. The book examines, among other things, photographs of lynching taken and distributed by the mob's apologists; early motion pictures that depicted mob executions; the notorious pro-lynching film, Birth of $a$ Nation; and later films with an anti-lynching message. In addition, Wood considers the use of images by opponents of mobbism. Rather than simply chronicling resistance to lynching, she dissects how activists constructed that opposition. Wood uses the concept of "witnessing," the "act of being a spectator." This allows her to examine the role not just of the lynch mob, but of white Americans more broadly, who participated in lynching through their spectatorship of lynching images. Wood argues that witnessing was also a tactic used by anti-lynching activists. Her work is important because she explores the "cultural power" of lynching, which, she explains, "rested in spectacle." 4

My own work on mob violence, which considers the NAACP's anti-lynching activism and the arts, also focuses on representations-or narratives, as I tend to term them-of 
lynching. The retelling of the lynching story was an important aspect of the phenomenon. Lynching narratives justified and celebrated the act. They allowed lynchers to reenact it, and in so doing, reinforced messages of Black vulnerability. These narratives became increasingly standardized and allowed those whites who hadn't witnessed a lynching firsthand to 'read' the ideology of white supremacy. They formed a record of racial violence that blamed the victim and exonerated white mobs. Alternative narratives were constructed by Black artists, writers, and activists in the early twentieth century, which challenged white representations of lynching. African Americans thus created a new record of lynching and of Black resistance. ${ }^{5}$

Wood explores the use of photographs by anti-lynching activists. Lynching photographs were initially created by whites for an intended white audience. In their original form they "served to normalize and make socially acceptable, even aesthetically acceptable, the utter brutality of lynching" and "provided seemingly indisputable graphic testimony to white southerners' feelings of racial superiority." Anti-lynching activists then took these photos and "bestowed on them an entirely different kind of authority." By changing the context, "viewers were ... impelled to read the images oppositionally, that is, against their intended point of view." 6 The artists and writers that I discuss in my work created their representations from that oppositional view, impelling their viewers or readers to see them as indictments of white brutality and (meditations on) African American suffering. Both the artists and the activists changed the context of lynching representations, transforming the standardized white supremacist narrative in the process.

When reading Wood, I was struck by her analysis of a rhetorical shift in Black activism. She argues that after the First World War activists did not explain lynching as the product of racist structures and institutions but rather increasingly "attacked lynch mobs ... as disgraces to democracy and modern civilization." Lynching was presented as an American, rather than a particularly southern form of injustice. Anti-lynching activists used this rhetoric to appeal to white liberals and moderates in the North and the South. There were more detailed denunciations of lynching that explained them as products of racism but, for the most part, anti-lynching rhetoric and imagery "made surprisingly little mention of race or racial prejudice." Moreover, the white mob, rather than the Black victim, was at the center of the anti-lynching discourse. ${ }^{7}$ Wood's argument led me to rethink my own analysis of anti-lynching rhetoric and to ask whether it applied to the examples of lynching narratives in my work. I found that the Black female playwrights examined in my chapter (including Angelina Weld Grimké, Georgia Douglas Johnson, and Alice Dunbar Nelson) did situate lynching within a wider context of racial prejudice. They frequently linked mob violence to social and economic injustice. Many pieces attempted to reclaim the victim's humanity, by placing him (the victim in these representations was usually male) in the context of a family and home, giving him a name. These writers, alongside Black visual artists (such as Hale Woodruff, Allan Freelon, and Wilmer Jennings), centered the Black victim. When comparing the different forms of anti-lynching discourse, it is interesting that a more nuanced and detailed critique of lynching actually took place in artistic treatments of lynch violence. This helps explain why an organization such as the NAACP used culture in its response to lynching.

In Lynching in the New South, Brundage examines the response of both white and Black southerners to lynching in Virginia and Georgia. These reactions varied, depending on the context of both time and place. He found, for example, that there was some white opposition to lynching because of conservative concerns about the threat to social order and to the economic prosperity of their region. In Virginia, Black leaders and local 
institutions spoke out forcefully against mob violence. Black newspapers played a particularly important role in these efforts. African Americans in Georgia had to be more "furtive," particularly in the nineteenth century when there was no uniform response because of the extreme constraints under which they lived. Black options included flight and self-defense. In the later period, migration became an effective means by which African Americans could alleviate their oppression. In both states, Brundage discusses the local work of the NAACP and its attempts to organize, protest, and provide legal protection. He concludes that, in general, African American efforts to fight against lynching were understandably limited in scope and effectiveness. ${ }^{8}$ Subsequent studies by Wood and then myself have helped to broaden our understanding of what might be deemed 'responses' to lynching. We both read cultural sources as examples of opposition to mob violence. African Americans, and white allies, created counter narratives of lynching to challenge these barbaric practices. The intention was to try to change attitudes toward lynching through these representations. This work tended to take place on a national, rather than local, level, which may account for the difference between Brundage's study and later assessments of responses. It also reflects a move on the part of scholars such as Wood and myself, to emphasize cultural efforts. By exploring the use of photographs, films, poetry or painting, it allows us to uncover the breadth of African American resistance. This, I believe, is why, as scholars, we should to examine these cultural artifacts in our assessments of racial violence.

It is similarly important that we use a range of sources when teaching the history of lynching, including artistic representations. For example, I might begin a lecture by playing a recording of Billie Holiday singing "Strange Fruit" or use images from the NAACP's anti-lynching art exhibition in my slides. For a number of years, I have taught a module to first-year undergraduates that reflects on the nature of 'modernity' and the development of a 'modern' world in Western society. The module takes a case study approach and I use the topic of lynching, in part, to challenge students' assumption that modernity equals progress. After outlining the context and nature of lynching, I explain to students, as Woods does to her readers, that activists and scholars in the early twentieth century saw lynching as a traditional form of retribution. It was grounded in the past, just as the South was seen as a region wedded to the past. They believed that as the South developed it would reject these barbaric forms of entertainment. ${ }^{9}$ There are more recent scholars who also argue that lynchings took place because of the absence of modernity in the South. ${ }^{10}$ But then I ask students to think about the relationship between modernity and mob violence in another way. We consider whether lynchings occurred because the South was transforming into a modern society. Hale has argued that lynching became a "peculiarly modern ritual." It was a "key medium for resolving the contradictions within the culture of segregation." She explains that mob violence depended on modern transportation and technologies and reflected modern consumption practices. So we discuss the use of cars and trains, telegrams and telephones, and cameras in mob violence. $^{11}$

Lynching and Spectacle is useful for developing this argument with students. It considers the uncertainties of the era and the ways in which class and racial hierarchies had been disrupted. Traditional forms of authority were challenged and separation of the races was threatened as urban spaces brought white and Black people together. White people were searching for ways to emphasize the difference between themselves and African Americans, and lynchings provided one such way. "White supremacy and white solidarity were not certainties - they were ideologies that needed to be constructed and established and that required constant replenishing and constant reenvisioning. That is, 
they needed to be performed and witnessed." 12 The context of the South's reaction to modernity was crucial to understanding lynching; a point that Brundage made in his work when exploring the role of industrialization and the rapid expansion of the market economy. ${ }^{13}$ The history of lynching is thus useful for exploring the meanings and implications of modernity in the United States.

Lynching is a difficult, but important, topic to teach undergraduate history students. If I am teaching a broad survey module, with little American or specifically African American history, then I often include a discussion of lynching. As Wood argues at the start of her book, lynching "came to stand as the primary representation of racial injustice and oppression as a whole." ${ }^{14}$ Mob violence was one of the most powerful examples of the reality of Jim Crow. Studying it helps students to understand the vulnerability of African Americans. It also allows them to comprehend that white supremacy wasn't an established ideology. As a teacher, it allows me to challenge any misconception students may have that segregation and discrimination were inevitable; to show that they had to be worked on and maintained. I also believe that we shouldn't talk about lynching without discussing African American resistance to lynching. Mob violence doesn't just demonstrate Black vulnerability, it also shows incredible resilience in the face of this brutality. Anti-lynching campaigns are useful examples of late nineteenth- and early twentiethcentury Black activism, which broadens students' understanding of what Black activism means and demonstrates its long roots. It is also a great topic because I get to introduce them to Ida B. Wells, a Black female activist, who also may challenge some preconceptions about who should be considered a civil rights leader.

Most recently, lynching became part of my teaching when I included it in a module about African American Memory. In this course we explore the ways in which Black Americans have constructed, challenged, and been excluded from historical memories. I added lynching to the syllabus after reading about the new memorial to victims of white terror that has opened in Montgomery. This highlighted to me the continuing struggle to make sure the story of lynching is told. Activists in the twenty-first century are doing what their predecessors did in the nineteenth and early twentieth centuries. So I revisited the scholarship on lynching and considered the place of mob violence in communal memories. As Wood notes, white southerners repressed memories of lynching. "Communities that had previously celebrated lynching ... began to maintain a sort of embarrassed and horrified silence about it" and came to "deliberately omit stories of lynching" from public memory. ${ }^{15}$ But I am less interested in why and how white Americans forgot lynching, as I am in African American efforts to remember.

This remembering can be a fraught process, not least because lynchings, as scholars such as Wood recognize, got much of their power from retelling. The writer Angelina Weld Grimké explained, "That people could see and hear about these events far away from and long after the fact of their occurrence is part of the act of lynching itself, for representations not only function to preserve the act in perpetuity, they also allow the act to be committed again." ${ }^{16}$ This creates a quandary, which I present to my students: Is it possible to remember lynching without reenacting it and allowing it to be committed again? How can a community remember something so traumatic? Earlier in the module we discuss memories of slavery, a horrific part of the African American experience. But memories of the trauma of enslavement could be counterbalanced by communal memories of eventual emancipation, as well as recollections of resistance and culture and family. Whereas, there is nothing transformative about the memory of lynching. Why, then, is there, and has there always been, such an insistence on remembering? 
The Equal Justice Initiative's report into lynching opens with the following quote from Maya Angelou, which explains why activists want to remember the practice of mob violence. "History, despite its wrenching pain / Cannot be unlived, but if faced/ With courage, need not be lived again." 17 The director of the Equal Justice Initiative, Bryan Stevenson, explained, "We cannot heal the deep wounds inflicted during the era of racial terrorism until we tell the truth about it." ${ }^{18}$ In African American culture there is a "commemorative vigilance," a desire not to forget, which leads to the creation of "sites of memory." 19 I explore some of these "sites" of lynching memories with students, including anti-lynching plays and artwork. I use Wood's idea of "bear[ing] witness to white injustice and brutality" to explore the power of these anti-lynching memories. ${ }^{20} \mathrm{We}$ consider, for example, the lynching of Mary Turner and the artistic responses to her killing, such as Meta Warrick Fuller's sculpture and Angelina Grimké's short story, "Goldie." In the module assessment, in which students can choose their own case study, students wrote about these and other related examples, such as the Equal Justice Initiative Report on Lynching, the National Memorial for Peace and Justice, and Angelina Weld Grimké's play, Rachel.

In preparing to teach this topic, I borrowed some material from my research and book but used a different framework. While I discuss the practice of 'remembering' in my book, I wasn't much concerned with historical memory as a concept. My recent interest in this approach has caused me to revisit and reconsider my earlier research. This, to my mind, is one of the most interesting directions that scholarship on lynching is taking. Studies such as Wood's are helpful in this respect, as they can strengthen our interpretation of lynching's representations. These representations can often be understood as memories. There has already been some important work on lynching and memory. For example, Bruce E. Baker's essay on a number of lynchings in South Carolina, in which he identifies different "communities of memory," and documents what and how those "communities" chose to remember and forget. Jonathan Markowitz's Legacies of Lynching explores lynching as a metaphor for race and considers some collective memories of mob law, including those in motion pictures. Angela Sims's Lynched: The Power of Memory in a Culture of Terror, based on oral history interviews with elderly African Americans, explores the theological significance of lynching memories. African American reactions to lynching are also examined by Karlos K. Hill; particularly interesting is his idea of the "consoling narrative" as a form of resistance, constructed, for example, in Black oral memory. Kidada E. Williams has produced a significant study, which foregrounds the experiences of Black victims of racial violence. She uses the term "vernacular history" to describe these African American testimonies, but we might also consider them as "sites of memory." African Americans were deliberately ensuring that their memories of violence were noted and preserved. ${ }^{21}$

If we take African American responses to mob violence, the focus of this important recent scholarship, as the starting point, it opens up new avenues to explore individual and collective acts of remembering. How did families and local communities remember the lynchings that befell them? What of a wider African American community? What is the relationship between artistic and vernacular memories of lynching? What are some of the sites of memory for racial violence? For example, how can we read Black newspapers as repositories of lynching memories? And how, as historians, should we interpret twenty-first-century efforts to memorialize lynching? The contemporary relevance of lynching memories is clear in the age of Black Lives Matter, and the role these memories can play in the fight for racial justice is highlighted in projects such as those of the Equal 
Justice Initiative. This is why teachers and researchers should continue to explore and expose the brutal reality of America's past: why we too should bear witness.

\section{Notes}

1 Amy Louise Wood, Lynching and Spectacle: Witnessing Racial Violence in America, 1890-1940 (Chapel Hill: University of North Carolina Press, 2009).

2 In this essay, and in my teaching, I often use 'lynching' as a shorthand for white supremacist violence that increasingly specifically targeted African Americans and which, as the twentieth century progressed, predominantly took place in the South. Lynching, as much of the scholarship in this journal edition demonstrates, took other forms, in different locations, and was perpetrated against diverse groups. However, the understanding of lynching that dominates popular memory is that of a phenomenon that targeted African Americans, and so it is a useful way to engage students in the history of white supremacy, and to spark discussions about how lynching is remembered.

3 W. Fitzhugh Brundage, Lynching in the New South: Georgia and Virginia, 1880-1930 (Urbana: University of Illinois Press, 1993).

4 Wood, Lynching and Spectacle, 2, 3. An important study of the power and use of images of mob violence is Dora Apel, Imagery of Lynching: Black Men, White Women and the Mob (New Brunswick, NJ: Rutgers University Press, 2004).

5 Jenny Woodley, Art for Equality: The NAACP's Cultural Campaign for Civil Rights (Lexington: University Press of Kentucky, 2014).

6 Wood, Lynching and Spectacle, 75-76, 183, 186.

7 Wood, Lynching and Spectacle, 204-205.

8 Brundage, Lynching in the New South, Chapter 6, 7, and 8.

9 Wood, Lynching and Spectacle, 5.

10 Hale references James McGovern, Joel Williamson, and Jacquelyn Dowd Hall. Grace Elizabeth Hale, Making Whiteness: The Culture of Segregation in the South, 1890-1940 (New York: Vintage Books, 1998), 202.

11 Hale, Making Whiteness, 202-203. Also useful is Goldsby, who argues that lynchings "flourished as registers of the nation's ambivalences attending its nascent modernism." Jacqueline Goldsby, A Spectacular Secret: Lynching in American Life and Literature (Chicago: University of Chicago Press, 2006), 24.

12 Wood, Lynching and Spectacle, 7-8.

13 Brundage, Lynching in the New South, 14.

14 Wood, Lynching and Spectacle, 1.

15 Wood, Lynching and Spectacle, 263.

16 Grimké quoted in David Krasner, A Beautiful Pageant: African American Theatre, Drama, and Performance in the Harlem Renaissance, 1910-1927 (New York: Palgrave Macmillan, 2002), 105.

17 Maya Angelou, "On the Pulse of Morning," quoted in Equal Justice Initiative, Lynching in America: Confronting the Legacy of Racial Terror (3d ed., 2017).

18 Equal Justice Initiative, https://eji.org/reports/lynching-in-america

19 Pierre Nora quoted in Geneviève Fabre and Robert O'Meally, eds., History and Memory in AfricanAmerican Culture (New York: Oxford University Press 1994), 7.

20 Wood, Lynching and Spectacle, 183.

21 Bruce E. Baker, "Under the Rope: Lynching and Memory in Laurens County, South Carolina" in Where These Memories Grow: History, Memory, and Southern Identity, ed. W. Fitzhugh Brundage (Chapel Hill: University of North Carolina Press, 2000); Jonathan Markowitz, Legacies of Lynching: Racial Violence and Memory (Minneapolis: University of Minnesota Press, 2004); Angela Sims, Lynched: The Power of Memory in a Culture of Terror (Waco: Baylor University Press, 2016); Karlos K. Hill, Beyond the Rope: The Impact of Lynching on Black Culture and Memory (New York: Cambridge University Press, 2016); Kidada E. Williams, They Left Great Marks on Me: African American Testimonies of Racial Violence from Emancipation to World War I (New York: New York University Press, 2012). 
Jenny Woodley is a Senior Lecturer in Modern History at Nottingham Trent University. She is the author of Art for Equality: The NAACP's Cultural Campaign for Civil Rights (University Press of Kentucky, 2014). Her current research project, funded by the British Academy, investigates the opportunities and spaces for remembering and mourning Black victims of lynching.

Cite this article: Jenny Woodley, "“Witnessing” Lynching in Scholarship and in the Classroom,” The Journal of the Gilded Age and Progressive Era 20, 122-128. https://doi.org/10.1017/S1537781420000547 